\title{
Correlates of Conflict, Power and Authority Management, Aggression and Impulse Control in the Jamaican Population
}

\author{
G Walcott ${ }^{1}$, FW Hickling ${ }^{2}$
}

\begin{abstract}
Objective: The object of this study is to establish the correlates of the phenomenology of conflict and power management in the Jamaican population.

Methods: A total of 1506 adult individuals were sampled from 2150 households using a stratified sampling method and assessed using the 12 questions of the Jamaica Personality Disorder Inventory (JPDI) on the phenomenology of conflict and power management that are grouped into the psychological features of aggressive social behaviour, unlawful behaviour, socially unacceptable behaviour and financial transgressive behaviour. The database of responses to the demographic and JPDI questionnaires was created and analysed using the Statistical Package for the Social Sciences (SPSS) version 17.

Results: Of the national population sampled, $69.1 \%$ denied having any phenomenological symptoms of abnormal power management relations while $30.9 \%$ of the population admitted to having some degree of conflict and power management, ranging from mild (10.3\%), to moderate (17.1), or severe (3.5\%). There were $46.55 \%$ of the population which had problems with aggressive social behaviour, $9.33 \%$ had problems with unlawful behaviour, 9.58\% had problems with unacceptable social behaviour and $37.74 \%$ had problems with financial transgressive behaviour. Significant gender and socio-economic class patterns for conflict and power management were revealed. This pattern of conflict and power management behaviour is critical in understanding the distinction between normal and abnormal expression of these emotions and actions.

Conclusion: Nearly one-third of the sample population studied reported problems with conflict, abnormal power and authority management, impulse control and serious aggressive and transgressive behaviour.
\end{abstract}

Keywords: Aggression, authority management, conflict, impulse control, Jamaica Personality Disorder Inventory, Jamaica population, personality disorder, power management

\section{Correlatos de Conflicto, Poder y Manejo de la Autoridad, Agresividad y Control de los Impulsos en la Población Jamaicana}

G Walcott ${ }^{1}$, FW Hickling ${ }^{2}$

\begin{abstract}
RESUMEN
Objetivo: El objeto de este estudio es establecer los correlatos de la fenomenología del manejo de conflicto y poder en la población jamaicana.

Métodos: Se tomaron muestras de un total de 1506 individuos adultos de 2150 hogares, usando un método de muestreo estratificado, y se evaluaron usando las 12 preguntas del Inventario de Trastornos de la Personalidad en Jamaica (JPDI) sobre la fenomenología del manejo del conflicto y el poder, clasificadas como características psicológicas del comportamiento social agresivo, comportamiento ilícito, comportamiento socialmente inaceptable, y conducta financiera transgresora. La base de datos
\end{abstract}

From: ${ }^{1}$ South East Regional Health Authority, Kingston and St Andrew Public Health Service, 1 Marescaux Road, Kingston 5 and ${ }^{2}$ Caribbean Institute of Mental Health and Substance Abuse, The University of the West Indies, Kingston 7, Jamaica, West Indies.
Correspondence: Dr G Walcott, South East Regional Health Authority, Kingston and St Andrew Public Health Service, 1 Marescaux Road, Kingston 5, Jamaica. E-mail: dr.gwalcott@gmail.com 
de respuestas a los cuestionarios de demografía y JPDI, fue creada y analizada utilizando el Paquete Estadístico para Ciencias Sociales (SPSS) versión 17.

Resultados: El 69.1\% de la población nacional muestreada negó tener sintoma fenomenológico alguno de relaciones de poder anormal, mientras que el 30.9\% de la población admitía haber tenido algún grado de manejo de conflicto y poder, fluctuando de leve (10.3\%) a moderado (17.1), o severo (3.5\%). Hubo $46.55 \%$ de la población con problemas de comportamiento social agresivo, 9.33\% tuvo problemas de comportamiento ilegal, 9.58\% tenían problemas de comportamiento social inaceptable, y $37.74 \%$ tuvo problemas de comportamiento financiero transgresor. Se pusieron de manifiesto de forma significativa patrones de género y clase socioeconómica con respecto al manejo de conflicto y poder. Este patrón de comportamiento de manejo de conflicto y poder es un factor crítico para entender la distinción entre la expresión normal y anormal de estas emociones y acciones.

Conclusión: Casi un tercio de la población de la muestra estudiada reportó problemas con el manejo de conflicto, poder anormal y autoridad, control de impulsos, y serio comportamiento agresivo y transgresor.

Palabras claves: Agresión, manejo de la autoridad, conflicto, control de impulsos, Inventario de Trastornos de la Personalidad en Jamaica, población de Jamaica, trastornos de la personalidad, manejo de poder

West Indian Med J 2013; 62 (5): 406

\section{INTRODUCTION}

Power is defined as the ability or capacity to do something or act in a particular way; the capacity or ability to control, have authority over or to influence the behaviour of others or the course of events (1). Power management refers to an individual's ability to manage power within them and to manage power relationships between themselves and others, and is derived from the 'discipline of the social environment' embodied in social order that integrates our ways of behaviour, starting with the process of feeding, toilet-training, locomotion or grasping (2). People are fundamentally sociable and interact with others in order to construct and participate in one or another of the basic types of social relationships (3). Abnormality in power management relations refers to an individual's difficulty in controlling drives that underlie his or her ability to control impulses that manage intrapersonal and interpersonal power relationships. This abnormality is constructed of a constellation of emotions and behaviours such as anger, rage, insecurity, manipulativeness and competitiveness, which may be expressed individually or melded, and are repeatedly exhibited at pathological levels, frequently resulting in interpersonal difficulties across social domains (4). Power management abnormality invariably leads to conflict. Studies at The University of the West Indies (UWI), Section of Psychiatry, have identified that abnormal power management is one of a triad of phenomenological entities that define psychopathology in the Jamaican population (5, 6). This led to the development of a 38-question screening instrument for personality disorder, the Jamaica Personality Disorder Inventory (JPDI) based on the phenomenological clinical triad of power management, dependency and sexual issues in patients with personality disorder (7), which in turn led to the study of the prevalence of personality disorder in a stratified sample of the Jamaican population (8). This present study centres on the responses of the stratified Jamaican population sample to the 12 questions that focussed on the phenomenology of power management, aggressive behaviour, impulse control and conflict. The object of this present study is to delineate the correlates of the phenomenology of power management in the Jamaican population.

\section{SUBJECTS AND METHODS}

A total of 1506 adult individuals were sampled from 2150 households using a stratified sampling method to reflect the demographics of the general population. The survey was conducted by Market Research Services Limited (9), a Jamaican market research firm with almost 30 years of experience in conducting market research programmes in Jamaica and across the Caribbean. A four-stage stratified random sampling method was used to identify the target population. The population was assessed using the JPDI. The methodology is described elsewhere (8).

\section{Diagnostic measures}

Jamaica Personality Disorder Inventory (JPDI)

The JPDI is a 38-item interviewer administered questionnaire that was developed by The UWI, Section of Psychiatry, as a screening tool to identify the probability of being diagnosed with a personality disorder. Taking approximately 30 minutes for administration, the JPDI is intended to be linguistically simple and relevant to the reconceptualization of personality disorder. The JPDI has demonstrated reliability and criterion-related and discriminant validity (7). The JPDI has questions that were carefully designed by a focus group of psychiatrists and psychologists from The UWI to 'capture' the three phenomena of the 'clinical triad' of personality 
disorder (6). The questionnaire is divided into three categories: physiological and psychological dependency (questions 1 to 17), power management (questions 18 to 29) and psychosexual issues (questions 30 to 37). The JPDI's 12 questions on the phenomenology of power are grouped into four sub-groups that attempt to cull critical aspects of abnormal power management in the areas of aggressive social behaviour features (questions 18-21); unlawful behaviour (questions 22-23), socially unacceptable behaviour (questions 24-26) and financial transgressive behaviour (questions 27-29). The 12 questions investigating the psychology of abnormal power management are displayed in Table 1 .
SEC 5 (working class and lowest level of subsistence). There were 155 persons in SEC 1-3 and 387 in SEC 4 and the majority in SEC 5 (Table 2).

The cumulative responses (scores) to power management questions

With each question scoring yes (positive response, scoring 1), or no (negative response, scoring 0 ) the cumulative maximum negative responses were scored for the entire population and the total cumulative positive responses were scored for the questionnaire. An analysis of these scores revealed that $30.9 \%$ of the population admitted to having

Table 1: The Jamaica Personality Disorder Inventory (JPDI) power management questions and psychological correlates

\begin{tabular}{lll}
\hline No & JPDI items - power management & Category of conflict \\
\hline 18 & Do you have disagreements almost every day? & Aggressive social behaviour \\
19 & Do you have quarrels almost every day? & Aggressive social behaviour \\
20 & Are you involved in physical fights? & Aggressive social behaviour \\
21 & Do you take things that do not belong to you? & Aggressive social behaviour \\
22 & Have you been arrested? & Unlawful behaviour \\
23 & Have you ever been imprisoned? & Unlawful behaviour \\
24 & Have you ever been fired or demoted from a job? & Socially unacceptable behaviour \\
25 & Have you ever been expelled/suspended from school? & Socially unacceptable behaviour \\
26 & Have you been expelled from church? & Socially unacceptable behaviour \\
27 & Do you pay your bills late? & Financial irresponsibility \\
28 & Do you borrow money from people? & Financial irresponsibility \\
29 & Have you ever been evicted from rented premises? & Financial irresponsibility \\
\hline
\end{tabular}

Questions 18-21 reflect issues with impulse control, whereas questions 22-26 invariably reflect an authority management problem.

\section{Statistical analysis}

The database of responses to the demographic and JPDI questionnaires was created and analysed using the Statistical Package for the Social Sciences (SPSS) - version 17. Chisquared analysis was used to assess the differences in the responses for the population seen within a range of sociodemographic characteristics.

\section{RESULTS}

\section{Demographic}

The total population sample for this study was 1506 persons with 727 males and 779 females. The sample was divided into age groups with more than half the population being within the age range 25 to 44 years. There were 574 persons in lasting, meaningful relationships and 932 persons not in lasting, meaningful relationships. The persons were recruited from the fourteen parishes of Jamaica with 694 persons recruited from urban centres and 812 from rural areas. The persons were divided into three groups for socioeconomical class (SEC) using the UK Registrar General's Classification by Occupation (10), SEC 1-3 (upper, middle and lower middle class), SEC 4 (skilled working class) and
Table 2: Demographics

\begin{tabular}{rlc}
\hline \multicolumn{2}{c}{ Demographic } & Number (\%) \\
\hline \multirow{2}{*}{ Gender } & Male & $727(48.3)$ \\
& Female & $779(51.7)$ \\
Relationship status & In relationship & $574(38.1)$ \\
& Not in relationship & $932(61.9)$ \\
& & \\
& $18-24$ & $281(18.7)$ \\
Age & $25-34$ & $399(26.5)$ \\
(year) & $45-54$ & $388(25.8)$ \\
& $55-64$ & $263(17.5)$ \\
Socio-economic status & SEC 1-3 & $175(11.6)$ \\
& SEC 4 & $155(10.3)$ \\
& SEC 5 & $387(25.7)$ \\
Location & Rural & $964(64)$ \\
& Urban & $812(53.9)$ \\
\hline
\end{tabular}

some of the power management phenomenology problems. As the questionnaire allowed for people to answer on a Lickert scale of $0-5$ for severity, it was possible to categorize the number of positive responders with total cumulative scores ranging from mild $(10.3 \%)$, to moderate $(17.1)$, or severe $(3.5 \%)$ [Table 3]. 
Table 3: Cumulative numbers of responders for all 12 power management questions ranked for degree of severity

\begin{tabular}{lrrc}
\hline & Total score & Mean score & $\begin{array}{c}\text { Cumulative } \\
\text { percentage (\%) }\end{array}$ \\
\hline Never & 13423 & 1032.5 & 68.6 \\
Minimum & 1852 & 154.3 & 10.3 \\
Moderate & 3352 & 257.8 & 17.1 \\
Severe & 635 & 48.8 & 3.5 \\
\hline
\end{tabular}

The analysis of the total responses revealed that $46.55 \%$ of the population were responders who had problems with aggressive social behaviour, 9.33\% had problems with unlawful behaviour, 9.58\% had problems with unacceptable social behaviour and $37.74 \%$ had problems with financial transgressive behaviour (Table 4).

Gender and socio-economic analysis of positive responders The positive responders to the questions on aggressive and transgressive behaviour of power management were analysed for gender and socio-economic status (Table 5). The results revealed that for aggressive behaviour, women were more likely to engage in disagreements and quarrels with others $(p<0.000)$ while men were more likely to steal and have physical fights. The upper and middle class responders were more likely to have disagreements with others $(p<0.05)$ but there was no significant difference between socio-economic group for engaging in quarrels, fights, or taking things from others $(p>0.05)$.

\section{Unlawful behaviour}

Men were far more likely to engage in behaviour that resulted in arrests and imprisonment than women $(p>0.00)$. Responders from SEC 4-5 were more likely to engage in behaviour that resulted in police arrest than SEC $1-3(p<0.00)$; however, there was no significant social class difference in the responders to the questions of being imprisoned for criminal behaviour $(p>0.05)$.

Table 4: Positive power management question responders

\begin{tabular}{lccc}
\hline & Total positive responders & Total cohort responders & \% \\
\hline $\begin{array}{l}\text { Aggressive social behaviour } \\
\text { (questions 18-21) }\end{array}$ & 2804 & 6024 & 46.55 \\
$\begin{array}{l}\text { Unlawful behaviour } \\
\text { (questions 22, 23) }\end{array}$ & 281 & 3012 & 9.33 \\
$\begin{array}{l}\text { Unacceptable behaviour } \\
\text { (questions 24, 25, 26) }\end{array}$ & 433 & 4518 & 9.58 \\
$\begin{array}{l}\text { Financial transgressive behaviour } \\
\text { (questions 27, 28, 29) }\end{array}$ & 1705 & 4518 & 37.74 \\
\hline
\end{tabular}

Table 5: Positive responders by gender and socio-economic status for power management questions

\begin{tabular}{|c|c|c|c|c|c|c|c|}
\hline \multirow[t]{2}{*}{ Question number } & \multicolumn{2}{|c|}{ Gender } & \multirow[b]{2}{*}{$p$-value } & \multicolumn{4}{|c|}{ Socio-economic status } \\
\hline & $\begin{array}{c}\text { Male }=727 \\
\text { (n) } \%\end{array}$ & $\begin{array}{c}\text { Female }=779 \\
\text { (n) } \%\end{array}$ & & $\begin{array}{l}\text { SEC 1-3 } \\
=155 \\
\text { (n) } \%\end{array}$ & $\begin{array}{l}\text { SEC } 4 \\
=387 \\
\text { (n) } \%\end{array}$ & $\begin{array}{l}\text { SEC } 5 \\
=964 \\
\text { (n) } \%\end{array}$ & $p$-value \\
\hline \multicolumn{8}{|c|}{ a. Aggressive social behaviour } \\
\hline 18. Disagreements & $613(84.3)$ & $660(84.7)$ & $0.00 \mathrm{~s}$ & $139(89.7)$ & $341(88.1)$ & $793(82.3)$ & $0.02 \mathrm{~s}$ \\
\hline 19. Quarrels? & $440(60.5)$ & $535(68.7)$ & $0.00 \mathrm{~s}$ & $101(65.2)$ & $256(66.1)$ & $618(64.1)$ & $0.05 \mathrm{~ns}$ \\
\hline 20. Physical fights? & $231(31.8)$ & $190(24.4)$ & $0.00 \mathrm{~s}$ & $35(22.6)$ & $123(31.1)$ & $263(27.3)$ & $0.09 \mathrm{~ns}$ \\
\hline 21. Take things? & $84(11.6)$ & $51(6.5)$ & $0.00 \mathrm{~s}$ & $8(5.2)$ & $38(9.8)$ & $89(9.2)$ & $0.35 \mathrm{~ns}$ \\
\hline \multicolumn{8}{|l|}{ b. Unlawful behaviour } \\
\hline 22. Arrested? & $175(24.1)$ & $44(5.7)$ & $0.00 \mathrm{~s}$ & $6(3.9)$ & $48(12.4)$ & $165(17.1)$ & $0.000 \mathrm{vs}$ \\
\hline 23. Imprisoned? & $54(7.4)$ & $8(1.0)$ & $0.00 \mathrm{~s}$ & $4(2.6)$ & $16(4.1)$ & $42(4.3)$ & $0.84 \mathrm{~ns}$ \\
\hline \multicolumn{8}{|c|}{ c. Unacceptable behaviour } \\
\hline 24. Fired/Demoted? & $150(20.6)$ & $83(10.7)$ & $0.00 \mathrm{~s}$ & $14(9.0)$ & $60(15.5)$ & $159(16.4)$ & $0.23 \mathrm{~ns}$ \\
\hline 25. Expelled school & $110(15.1)$ & $55(7.0)$ & $0.00 \mathrm{~s}$ & $12(7.7)$ & $54(14.0)$ & $99(10.3)$ & $0.09 \mathrm{~ns}$ \\
\hline 26. Expelled church? & $20(2.8)$ & $15(1.9)$ & $0.08 \mathrm{~ns}$ & $6(3.9)$ & $11(2.8)$ & $18(1.9)$ & $0.304 \mathrm{~ns}$ \\
\hline \multicolumn{8}{|c|}{ d. Financial transgression } \\
\hline 27. Pay bills late? & $422(58.1)$ & $517(66.4)$ & $0.00 \mathrm{~s}$ & $92(59.4)$ & $241(62.3)$ & $606(62.9)$ & $0.00 \mathrm{~s}$ \\
\hline 28. Borrow money & 359 (49.4) & $339(43.5)$ & $0.12 \mathrm{~ns}$ & $61(39.4)$ & $163(42.1)$ & $474(49.2)$ & $0.02 \mathrm{~s}$ \\
\hline 29. Evicted? & $36(5.0)$ & $32(4.1)$ & $0.77 \mathrm{~ns}$ & $4(2.6)$ & $18(4.7)$ & $46(4.8)$ & $0.48 \mathrm{~ns}$ \\
\hline
\end{tabular}




\section{Socially unacceptable behaviour}

Men were more likely to be expelled from school and/or fired/demoted at work than were women $(p<0.000)$. There was no significant difference between the genders for expulsion from church $(p>0.05)$. There was no significant difference for socio-economic status for engaging in socially unacceptable behaviour that would lead to expulsion from school, work or church $(p>0.05)$.

\section{Financial transgressive behaviour}

In relation to questions of financial transgressive behaviour, women were more likely to pay bills late $(p<0.00)$. The lower socio-economic groups, namely SEC 4 and SEC 5, were significantly more likely to pay bills late or borrow money $(p<0.05)$ while there was no significant difference for socio-economic status for persons getting evicted from rented premises $(p>0.05)$.

\section{DISCUSSION}

Questions relating to abnormality in power management refer to an individual's difficulty in controlling drives that underlie their ability to manage internal and external power relationships. Interpersonal and social conflict is the inevitable consequence and outcome of each of the 12 power management questions. All the responders to the questions of unlawful behaviour were ipso facto admitting to issues of antisocial authority conflict and to a variety of behaviours invariably leading to conflict and difficulties in managing conflict. Implicit in the abnormal conflict management phenomena are psychological constructs of a constellation of emotions such as anger and rage and explicit behaviour such as aggression, manipulativeness and impulsive acting out. These phenomena are repeatedly exhibited at psychopathological levels frequently resulting in conflicts and interpersonal difficulties across social domains. Thus, conflict behaviour is critical in understanding the distinction between normal and abnormal expression of these responders. For instance, although anger is a normal human emotion, the frequency and intensity of the recurrent rage displayed by persons experiencing these abnormal power management questions is an expression beyond the normal manifestation of anger. It represents instead a pathological emotional state that is often a precursor to observable and measurable abnormal psychological behaviour, expressed as verbal or physical conflict, domestic fighting and violence. These behaviours are indicative of the responders' inability to appropriately manage intrapersonal and interpersonal power and/or authority challenges. In this context, such power management problems may also stimulate transgressive behaviour displayed as authority and regulatory management challenges, organizational suspension and/or expulsion, theft, police arrest, or prison sentences.

Jamaica, with a homicide rate of 53/100 000 in 2011, has the third highest rate of lethal violence in the world after El Salvador and Iraq (11). The analysis of the power man- agement questions of the JPDI revealed that approximately $30 \%$ of the population studied reported problems with abnormal power management, impulse control, authority management and conflict of varying severity. A critical finding of this study, however, identifies that these persons contrast significantly with nearly $70 \%$ of the cohort who reported an absence of abnormal power management responses. This group of people reflects the overwhelming majority of the Jamaican population who exhibit healthy lives that contrast sharply with the small group (9\%) of responders of the total cohort who freely admit significant personal power management problems that result in regular physical fights, expulsion from social organizations such as school and work, and transgressive behaviour that often leads to police arrest and imprisonment. The analysis by gender and social class revealed that men were much more likely to be involved in quarrels and physical fights irrespective of their social class, and were also more likely to be arrested and imprisoned. These findings suggest that Jamaican men are a significant high-risk group for problems with serious aggressive, impulsive and transgressive behaviour. Previous research internationally has shown significantly higher levels of impulsivity among psychiatric patients with conduct disorder, personality disorders, substance use disorders and bipolar disorder, compared to other psychiatric patients or healthy comparison subjects (12). The comparative significance for this minority of Jamaican men reflected in this cohort is compelling.

Early anthropological and socio-political studies of Jamaica that have focussed on the problem of personality development in Jamaica posit that the cultural tensions resulted from the conflicts between the African heritage and values of the majority population and the British attitudes and values imposed during slavery. English social psychologist Madeline Kerr in an earlier study in colonial Jamaica formulated social contradictions between the oppressive British State and the African slave population that have affected the development of personality in Jamaica severely. Her work suggested that these historical antecedents made it very difficult for Jamaicans to assimilate the idea of cooperation with a group without spectacular leadership and that this can be correlated to the lack of male leadership in the Jamaican family (13). Jamaican Political Sociologist, Carl Stone (14), suggested that British colonization and the plantation economy created a warped authority system that engendered personality disorder seen in present day Jamaica. He describes the 'dis' syndrome as a pattern of aggressive and assertive behaviour that results from an individual who perceives that he/she has been 'dissed' or disrespected, and suggests that this hypersensitivity about status is rife in Jamaica, and that aggression is a standard tool for asserting personhood. He concludes that the contemporary ongoing political struggles in Jamaica of competing ideologies, values and norms have resulted in disequilibrium of power that has weakened authority in all domains of social space which 
combined with high levels of verbal and physical aggression has been associated with "serious personality disorders in our culture" (15).

Reports in the Jamaican news and social media describe the horrendous atrocities such as callous beheading and murderous, often seemingly senseless behaviour in contemporary Jamaica (16). A recent social media blog reports "...Watching that bloodsport called the nightly news has become as frightening as watching a horror flick. Policeman kills pregnant woman. 5 women raped in one house. Careless bus driver mows down innocent bystanders. Angry mob hacks man to death. And on and on..." (17). Kepinski (2) reminds us that the problem of order is inseparably connected with the problem of authority and power, which is in turn linked not only with the rule of life preservation, but also with the rule of preservation of the species. The findings of this study are sobering reminders of the link between authority, power and murderous behaviour in Jamaica in recent years, and demands continued analysis of the psyche of Caribbean people as we continue to search for therapeutic solutions to this social crisis occurring in the aftermath of centuries of systematic colonial exploitation and oppression.

\section{CONCLUSION}

Nearly one-third of the sample population studied reported problems with conflict, abnormal power and authority management, impulse control and serious aggressive and transgressive behaviour.

\section{REFERENCES}

1. Brown L, ed. Power. The New Shorter Oxford English Dictionary. Oxford: Oxford University Press; 1993.

2. Kepiński A. Translated by Bomba J. Psychopathology of power. Archives of Psychiatry and Psychotherapy 2008; 2: 79-89.
3. Fiske AP. The four elementary forms of sociality: framework for a unified theory of social relations. Psychological Review 1992; 99: 689723.

4. Hickling FW, Walcott G, Paisley V. Shakatani: the phenomenology of personality disorder in Jamaican patients. West Indian Med J 2013; 62: 397-404.

5. Hickling FW, Martin J, Harrisingh-Dewar A. Redefining personality disorder in Jamaica. In: Hickling FW, Matthies BK, Morgan K, Gibson $\mathrm{RC}$, eds. Perspectives in Caribbean psychology. Kingston, Jamaica: CARIMENSA, The University of the West Indies; 2008: 263-88.

6. Hickling FW, Paisley V. Redefining personality disorder: a Jamaican perspective. Rev Panam Salud Publica 2011; 30: 255-61.

7. Hickling FW, Walcott G, Martin J. The creation and validation of the Jamaica Personality Disorder Inventory. West Indian Med J 2013; 62: 389-96.

8. Hickling FW, Walcott G. Prevalence and correlates of personality disorder in the Jamaican population. West Indian Med J 2013; 62: $443-$ 7.

9. Market Research Services Limited (MRSL) [homepage on the Internet]. Kingston, Jamaica: Market Research Services Limited [cited 2011 Aug 31]. Available from: http://www.mrsl.com.jm/

10. Rose D. Official social classifications in the UK [Internet]. Soc Res Update 1995; 9: 1-7 [cited 9 December 2009]. Available from: http:// sru.soc.surrey. ac.uk/SRU9.html

11. Krause K, Muggah R, Gilgan E. Global burden of armed violence. Cambridge: Cambridge University Press; 2011.

12. Moeller FG, Barratt ES, Dougherty DM, Schmitz JM, Swann AC. Psychiatric aspects of impulsivity. Am J Psychiatry 2001; 158: 178393.

13. Kerr M. Personality and conflict in Jamaica. London: Collins/ Sangster's; 1963.

14. Stone C. The anatomy of aggression. The Daily Gleaner. 1992 Oct 21.

15. Stone C. Values, norms and personality development in Jamaica. Paper presented at the National Consultation on Values and Attitudes, The University of the West Indies, Kingston, Jamaica [Internet]. 1992 Mar 23 [cited 2011 Aug 31]. Available from: http://gtuwi.tripod.com/ stonearticle.htm

16. Robinson C. 5 Days, 4 Beheadings - fourth decapitation in a week stuns nation. Nation reels from yet another decapitation. Sunday Observer. 2011 July 24: News. Available from htt://www.jamaicaobserver. com/news/Nation-reels-from-yet-another-decapitation_9287118

17. Super Heavy. Jamaica mad to raas! OG. NR; 2012. Available from: http://www.og.nr/ms/blogs-by-author/likeitis/8922-jamaica-mad-toraas.html\#.UhueddkkrOm 